\title{
INTERNALIZATION ANALYSIS OF ENVIRONMENTAL COSTS OF WASTEWATER TREATMENT IN THE VALENCIAN COMMUNITY, SPAIN
}

\author{
MARCOS GARCÍA LÓPEZ, BORJA MONTAÑO SANZ \& JOAQUÍN MELGAREJO MORENO \\ University Institute of Water and Environmental Sciences, University of Alicante, Spain
}

\begin{abstract}
The need for water resources currently demands the development of measures to improve the management of these resources and increase their availability. However, these measures have an environmental impact that must be considered when carrying them out. The Water Framework Directive establishes that the economic and environmental costs of the activities carried out must be recovered, because this is necessary to ensure the sustainability of these activities and the continuity in the use of natural resources. The purification and reuse of wastewater is an activity within the framework of the circular economy that intends to reduce the environmental impact of contaminated water discharges and to increase the available resources. The problem is that this activity, being part of the production process, is linked to an environmental impact due to the use of chemical components, the construction of the facilities and, especially, the intensive energy consumption of the purification stations, since part of the energy comes from non-renewable sources. This environmental impact must be internalized in the cost structures through additional measures to mitigate it, so the objective of this paper is to determine the state of such internalization. Analyzing the costs of purification stations, the annual report of the EPSAR (Public Entity for Wastewater Sanitation of the Valencian Community) and the reports of the Hydrographic Confederations of Júcar and Segura, we can determine that there is no internalization in the stations, it is low in the EPSAR but increasing with time and for the Confederations the situation is complicated, as they cannot even recover their financial costs and the creation of several additional measures has been suspended. Finally, it has been found that there are economies of scale in terms of energy consumption of this activity, as well as significant potential energy savings during the purification process.

Keywords: wastewater treatment, water reuse, environmental impact, environmental cost, energy cost, costs internalization, Valencian community.
\end{abstract}

\section{INTRODUCTION}

In the past, water was considered a renewable and infinite resource and, although it is renewable given that it comes from the natural cycle of water, its inadequate exploitation can turn it into a non-renewable resource. In addition, its geographical and temporary distribution is a major problem due to imbalances between available resources and water needs in multiple geographic areas [1].

Currently there are relevant problems of water stress in many areas of the world, including Spain. When demand exceeds availabilities, increasing competition for resources can be expected, leading to shortages and high pressure on them, increasing the likelihood of management conflicts and contamination problems and impacting negatively on health and the economic activity. Therefore, the growing scarcity leads to greater vulnerabilities of the economy against situations of drought and to a deterioration of the environmental quality of surface and underground water bodies [1].

Likewise, it should be considered that the incidence of droughts in Europe is not stable, but has increased by $20 \%$ since 1976 and, despite the increase in torrential rains, annual rainfall has to fall [2]. To this must be added the overexploitation of aquifers that, with the droughts, highlights the need to take measures in reference to water resources, since water is 
a fundamental resource and its correct exploitation is at the base of sustainable development, besides being the base of social demand [3]. Water quality must also be taken into account, since not all water is usable. The human through its activity produces discharges that contaminate water resources and, currently, the wastewater discharged is one of the main causes of this contamination, being mandatory its treatment before returning them to the natural cycle [3].

Wastewater is increasingly considered in the management of water resources, including the United Nations Organization focuses the 2017 report on wastewater, which considers whether the wastewater that is discharged is a problem or they are a valuable resource that is being wasted. Therefore, not only the environmental impact of the discharge of polluting water becomes important, but also the lack of use of water that may have a later use. The report shows how in the low-income countries only $8 \%$ of wastewater is treated, while in the more advanced countries this percentage reaches $70 \%$, which is much higher, but there is still room for improvement [4].

The increase registered by water supply provisions, together with the increase in population experienced by many urban areas, have made traditional sources of supply insufficient [5]. Therefore, the development of unconventional sources of supply is of fundamental importance, since it not only supposes a complement to traditional sources, but also reduces the contamination of the discharges, among other improvements such as the generation of employment derived from the activity of water purification and reuse.

However, it must be kept in mind that this is a costly activity, both in economic and environmental terms. The first derive from the need to build the necessary facilities, to have workers and to acquire the necessary inputs for the water treatment process. The seconds appear because the water treatment requires a production process, which needs the construction of facilities, the use of chemical components and a high energy consumption, all with its corresponding contamination. In the case of energy consumption, pollution arises from the main use of fossil fuels to generate energy.

\section{ECONOMIC AND ENVIRONMENTAL ASPECTS OF WASTEWATER TREATMENT AND REUSE}

\subsection{Environmental aspects}

The processes of wastewater treatment have a positive and necessary effect due to the scarcity of water resources that is suffered in many parts of the world. The main function of these processes is to increase the availability of water resources through the treatment of wastewater, which have a high pollutant load, so that they can be discharged into the natural environment with a lower environmental impact or reused in other activities thanks to the increase in its quality. However, this is a process that also has a negative aspect and not only in terms of economic cost, but also through the impact of the activity on the natural environment.

The definition of the impact on the natural environment is determined by the Water Framework Directive, which establishes that an activity has an impact according to its influence on the state of the ecosystems. This directive, in the "polluter pays" application, establishes the principle of cost recovery, both of economic and environmental costs [6].

A fundamental problem of environmental costs is the great difficulty to calculate them accurately, since it is very complicated to measure the value of natural resources due to their economic, environmental, social and cultural value [7]. In addition, the forms that the environmental impact can adopt are very varied and can affect each type of value differently. 
For example, Yongguan et al. [8] analysed the environmental cost of water pollution in the Chinese city of Chongqing, finding that such pollution has significant effects on health, plants, fish, animals and industry.

In the Valencian community the pressure on the water resources is very high, for that reason it is necessary to promote the unconventional water resources to increase the available resources and alleviate the tensions. In response to this, the sanitation tax is a tribute that aims to improve the state of the natural environment by financing the purification and reuse of water.

As well as costs, the purification of water has environmental benefits derived from the reduction of pollutants in urban wastewater, less pressure on water resources and less need for energy generation by the production during the treatment process of sludge with energy value.

In the same way as for the environmental cost of water treatment, these benefits are very complicated to quantify since they consist of a positive externality. However, in order to include these environmental benefits in the analyses in the same way as the costs, an attempt is made to approximate their economic value. Molinos et al. [9] calculate the shadow price of four pollutants as a method of assessing the environmental benefit derived from their elimination, obtaining values that would be approximately the price of agents in a perfectly competitive market, obtaining negative prices by being pollutants.

Along with the economic costs and benefits, for the analysis of projects related to water purification, environmental considerations must also be taken into account, so that the analysis is complete and the objectives of efficiency in the use of water resources and cost recovery can be correctly contemplated.

An important detail that should be taken into account on these costs and benefits is that the Water Framework Directive contemplates the possibility of eliminating the environmental objective if fulfilling it requires a disproportionate cost for the benefit of achieving it, which places even more emphasis on the need to perform the analysis and the actions in the most efficient way possible. In addition, measures proposed should be well received by the public, that is, in the analysis and decision-making processes should include public preferences [10].

\subsection{Economic aspects}

The economic cost of water purification is a fundamental aspect, since the activity is carried out through concessions to private companies, which will not be offered to carry it out if there is no economic benefit, so minimizing costs is key to attracting companies to manage the debugging. In addition, the costs minimization is associated with an efficient use of resources, so by achieving lower costs, the environmental impact can be reduced.

Another relevant point when talking about the costs of water treatment is the treatment given to these waters, since the higher water quality is required, the more complex and expensive the treatment and technology used will be, but also the advantages of purification will be better used.

As Fig. 1 shows, the treatment of $1 \mathrm{~m}^{3}$ of water to be ready to be poured has a cost of $0.27 €$, while if its quality is also increased so that the water is reusable and the rest of the water is included, this cost increases to $0.68 €$. These costs are clearly higher than those that must be assumed to supply natural water, the price of which makes reclaimed water uncompetitive and limits its ability to be financed through its sale. This fact supposes a lack of a significant income, because the obtained product recovers a very low part of the costs, which leaves a need of financing that the sanitation tax does not cover completely. 


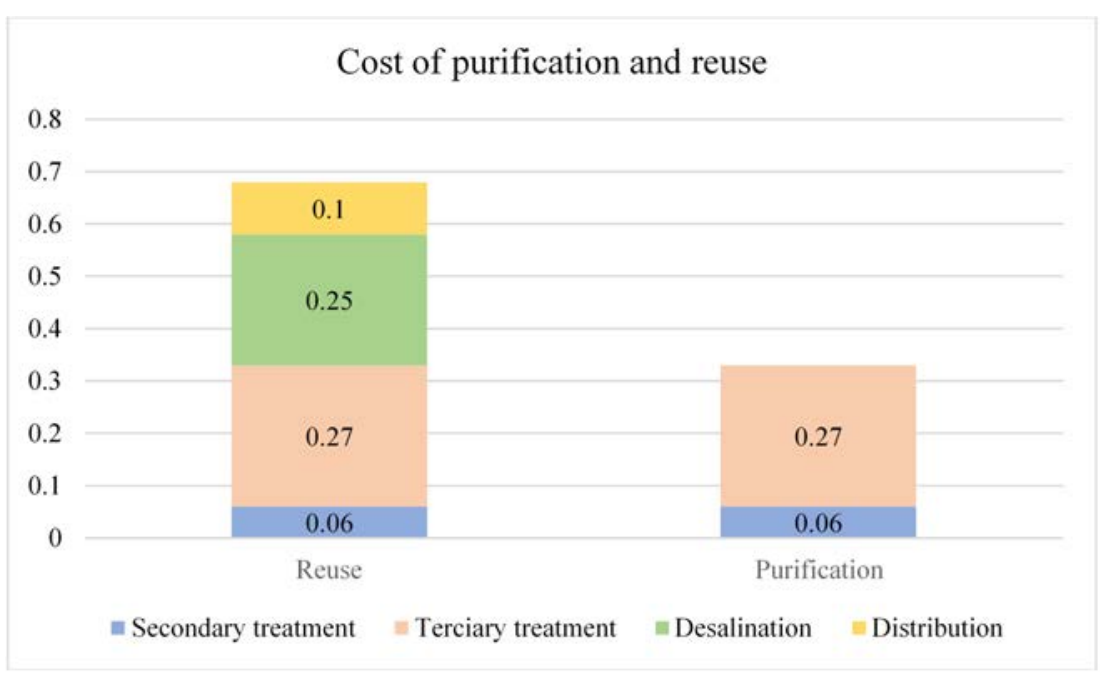

Figure 1: Exploitation cost of the purification and reuse, separately, of treated water in the Valencian community in $€ / \mathrm{m}^{3}$ for the year 2012. (Source: Comos [11].)

It must be kept in mind that the financing of costs, both economic and environmental, is fundamental and is closely related to the current water pricing policy. This policy has a threefold nature [12]: 1) remunerate the production factors that have participated in the process; 2) indicate through the price the degree of relative scarcity of the goods; and 3) complement other policies as the protection of the natural environment. In addition, the price policy can be used, according to the Water Framework Directive, as a redistribution of income, so that an objective of equity could also be pursued, but at the risk of suffering a loss of efficiency.

\section{INTERNALIZATION AND COST RECOVERY}

In Spain there is no market for reclaimed water, so you cannot get a price in this way and it is assumed that the maximum sale price should be equal to the cost per cubic meter, guaranteeing the cost recovery that the Water Framework Directive establishes, reason why to take it into account and to persecute it are two obligatory aspects. This cost recovery does not only mean economic self-sufficiency entering enough to offset the costs of implementation and exploitation, but also environmental costs through the polluter pays principle [6]. The objective pursued by the Water Framework Directive is that the Member States of the European Union design water pricing policies that provide incentives for users to make more efficient use of resources, so that the economic costs and pollution will be reduced thanks to the improvement in said efficiency.

If the price of reclaimed water is lower than its costs, even if its demand were stimulated, the obligation to find new sources of financing would arise, while if it is higher, its use with respect to the use of potable water would be discouraged. It should also be noted that for the construction of a purification station the price of reclaimed water is very important to know, in order to know if the project is going to be economically beneficial, since the management of purification stations is granted to private companies. Therefore, the water pricing policy is a fundamental factor in the planning of water resources, always taking into account the principle of cost recovery. 
Fig. 2 compares the domestic uses for consumption of 5,15 and $30 \mathrm{~m}^{3}$ of water, which allows to observe the progressivity of the tax. Thus, we find some communities where there is no progressivity and a greater consumption of water is associated with a lower price by dividing the fixed fee among more water. On the other hand, it is also possible to detect the presence of progressivity in places such as Andalucía, the Islas Baleares or Extremadura, where the consumption of $30 \mathrm{~m}^{3}$ of water shows a price per cubic meter higher than the other two consumptions.

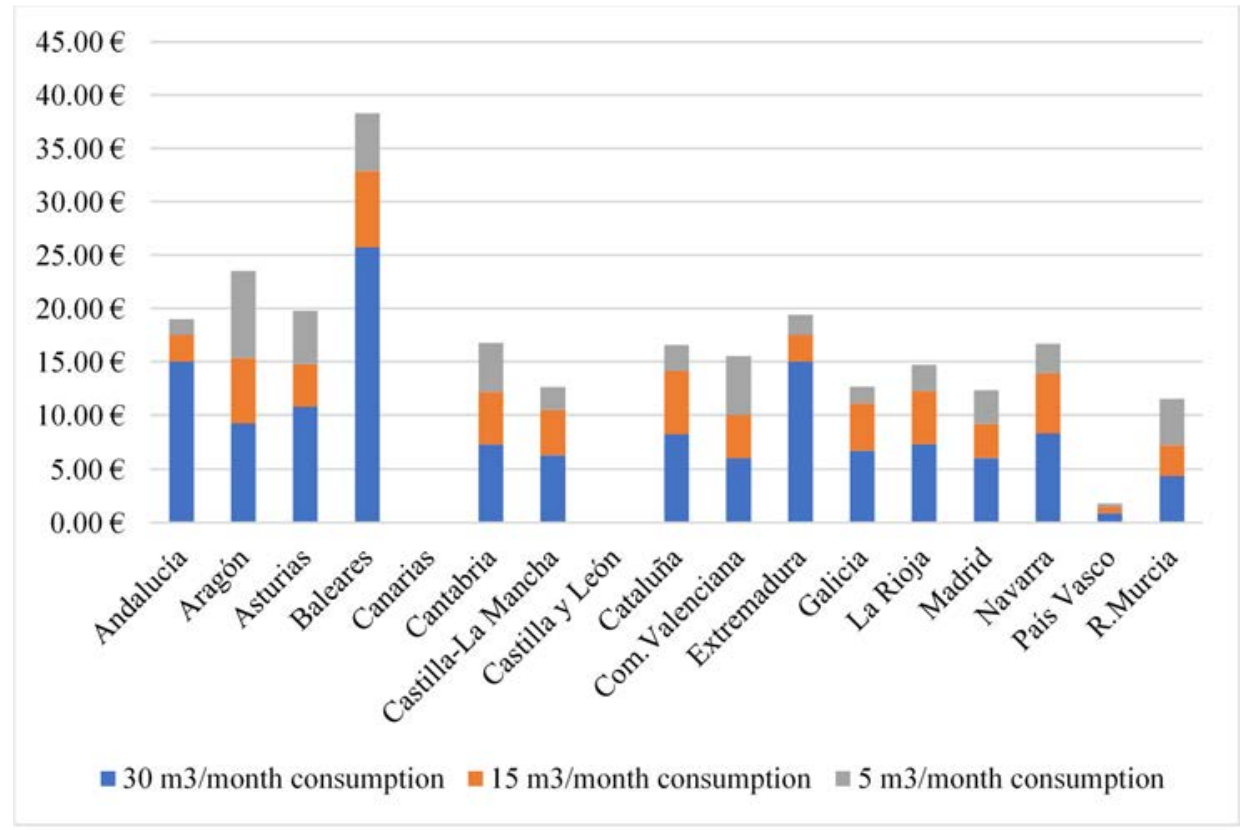

Figure 2: Monthly payment of sanitation tax for autonomous communities in case of consuming, for domestic use, 30, 15 or $5 \mathrm{~m}^{3}$ of water per month. (Source: Melgarejo and Esteve [13].)

However, the sanitation tax alone is not an indicator of cost recovery, since it is only the part of the revenue in terms of water purification and reuse, therefore the cost of this activity and the income and costs of the rest of the water policy must be taken into account. Table 1, shown below, contains the cost recovery levels of the inter-community hydrographic confederations of Spain for the reuse, the collection and purification of water in public networks and the total cost recovery of the water policy carried out for these entities. In addition, to consider the effect of the environmental impact, cost recovery is shown in terms of recovering financial costs and recovering total costs.

In the case of reuse, there are extreme cases among the confederations from the three that recover $100 \%$ of both financial and environmental costs, up to the two that recover $0 \%$ of both costs. The collection and treatment of wastewater is in a more complex situation. This table only includes the realization of this activity in public networks, which is what must be financed by the sanitation tax, allowing to observe that in any Hydrographic Confederation 
Table 1: Recovery of total costs, for reuse and for collection and purification of water in public networks in the inter-community hydrographic confederations of Spain. (Source: Own elaboration with data from the inter-community hydrographic confederations of Spain.)

\begin{tabular}{|l|c|c|c|c|c|c|}
\hline \multirow{2}{*}{ Plan 2015-2021 } & \multicolumn{2}{|c|}{ Reuse } & \multicolumn{2}{c|}{$\begin{array}{c}\text { Collection and } \\
\text { purification of water } \\
\text { in public networks }\end{array}$} & \multicolumn{2}{c|}{ Total } \\
\hline $\begin{array}{l}\text { Hydrographic } \\
\text { confederation }\end{array}$ & $\begin{array}{c}\text { Financial } \\
\text { costs }\end{array}$ & $\begin{array}{c}\text { Total } \\
\text { costs }\end{array}$ & $\begin{array}{c}\text { Financial } \\
\text { costs }\end{array}$ & $\begin{array}{c}\text { Total } \\
\text { costs }\end{array}$ & $\begin{array}{c}\text { Financial } \\
\text { costs }\end{array}$ & $\begin{array}{c}\text { Total } \\
\text { costs }\end{array}$ \\
\hline Cantábrico Occidental & $0 \%$ & $0 \%$ & $83 \%$ & $61 \%$ & $85 \%$ & $76 \%$ \\
\hline Cantábrico Oriental & $100 \%$ & $100 \%$ & $60 \%$ & $48 \%$ & $74 \%$ & $67 \%$ \\
\hline Ceuta & $100 \%$ & $100 \%$ & $48 \%$ & $43 \%$ & $69 \%$ & $56 \%$ \\
\hline Melilla & $100 \%$ & $100 \%$ & $31 \%$ & $31 \%$ & $41 \%$ & $40 \%$ \\
\hline Duero & - & - & $55 \%$ & $47 \%$ & $64 \%$ & $49 \%$ \\
\hline Ebro & - & - & $73 \%$ & $63 \%$ & $76 \%$ & $65 \%$ \\
\hline Guadalquivir & $100 \%$ & $49 \%$ & $84 \%$ & $73 \%$ & $83 \%$ & $74 \%$ \\
\hline Guadiana & - & - & $73 \%$ & $38 \%$ & $80 \%$ & $59 \%$ \\
\hline Tajo & $75 \%$ & $75 \%$ & $103 \%$ & $77 \%$ & $91 \%$ & $81 \%$ \\
\hline Júcar & $0 \%$ & $0 \%$ & $83 \%$ & $75 \%$ & $84 \%$ & $78 \%$ \\
\hline Segura & $8 \%$ & $3 \%$ & $81 \%$ & $46 \%$ & $83 \%$ & $57 \%$ \\
\hline Miño-Sil & - & - & $24 \%$ & $23 \%$ & $38 \%$ & $34 \%$ \\
\hline
\end{tabular}

Note: Information regarding the data used in this table can be found in the Appendix.

the costs of the activity are fully recovered. With the exception of the Tajo Confederation, not even the financial ones are recovered, so the recovery of costs is lower when adding the environmental and the resource to the financial ones. On the other hand, the worsening of the costs recovery when adding the environmental and the recourse to the financial ones is significant in the majority of confederations.

For the costs of all aspects of water policy, although the situation is generally better, an important part of the financial remains unrecovered and the level of cost recovery is far from $100 \%$ when taking into account the environmental and those of the resource.

This information shows that neither the internalization of environmental costs nor the recovery of total costs is taking place completely, but there are instruments to achieve them, since there is room to increase the price of water and the sanitation tax in the Valencian community.

However, although the sanitation tax of the Valencian community is lower than the imposed by other communities, it must be kept in mind that the budgetary situation of the EPSAR (Public Entity for Wastewater Sanitation of the Valencian Community) is solid. Since 2011 EPSAR income exceeds its costs, that is, it is not this entity that most urgently needs higher revenues to carry out its activity, but these higher revenues are generally necessary to achieve cost recovery of the services related to water.

\section{ENERGY COST AND ENVIRONMENTAL IMPACT OF WATER TREATMENT}

To the economic cost of water purification and reuse must be added an environmental impact that arises mainly from the high energy consumption associated with the exploitation, which represents a significant part of the total economic costs of the purification and an important 
pollution derived from the form of generation of the necessary energy. Taking into account the amount of processes that occur in a purification station, the relationship between water purification and energy consumption is very complex because each step of the process has a different energy cost [14].

To illustrate the general situation in Spain, Fig. 3 [15] shows the power required per unit of treatment, expressed in watts per equivalent inhabitant (vertical axis) and differentiated by municipality size (horizontal axis), as well as reflecting the potential energy saving in red. The graph shows that the larger the size of the municipality, the smaller the amount of energy required to purify the same amount of water, so there are economies of scale that lead to a lower unit cost when the quantity treated is higher. In addition, these differences based on size are very significant, which is evidence of the efficiency that can be achieved by treating large amounts of water for more populated municipalities.

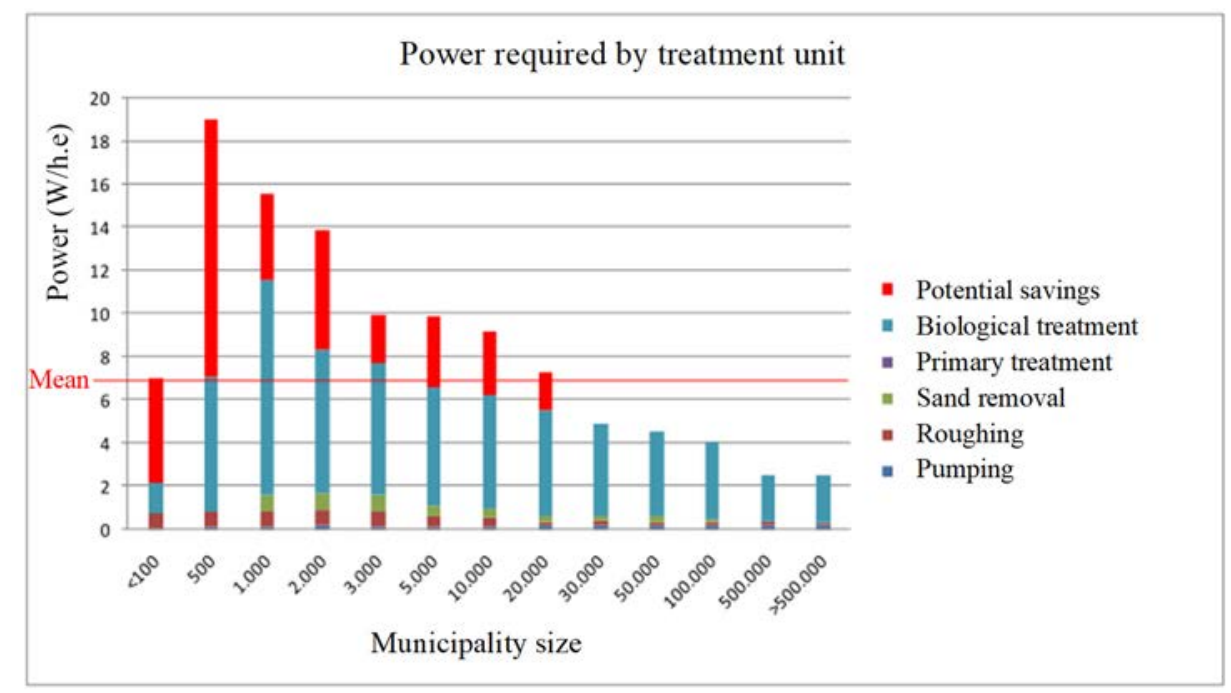

Figure 3: Energy required for the different wastewater treatments showing the part that could be saved. (Source: IDAE [15].)

As can be seen, the potential savings are very high, both in relative and absolute terms, which would imply a considerable economic saving and a reduction of the environmental impact derived from the energy consumption of purification station.

Focusing on the Valencian community, in EPSAR's own management report [16] it is explained that energy optimization measures are already being worked on, reducing the power consumption of the network continuously and reaching the weight of renewable energy the $19.5 \%$ of the total energy used, avoiding the consumption of 3,438 equivalent tons of oil.

Therefore, the EPSAR is considering the existence of an environmental impact by the purification and reuse of water, although the unavailability of specific information on the destination of the collection granted by the sanitation tax of the Valencian community, how much effort is being made to reduce this impact is very complicated. However, EPSAR [16] has carried out studies on the carbon footprint of purification stations in the Valencian 
community, reaching the conclusion that, although this remains high, the trend since 2010 is decreasing despite its stabilization in recent years.

Since the EPSAR takes into account the problem, has carried out studies and is promoting the installation of renewable energy sources at purification stations, it should not be considered that the environmental impact of the purification and reuse of water is being ignored. However, there is still a great margin for improvement, since $80.5 \%$ of the energy is still coming from non-renewable sources, with its respective emission of greenhouse gases, so the pending tasks in this aspect are mainly to improve energy efficiency to require lower consumption and stimulate the use of renewable energy by generating energy in the purification station itself.

\section{CONCLUSIONS}

Nowadays, thanks to the water treatment, it is possible to reuse a significant part of the wastewater, however, this amount could be even greater if efforts were made, which would be a great help to reduce the high pressure on the water bodies of the Valencian community.

The positive contribution of water treatment to the state of the water bodies is remarkable, but it also has a negative effect that must be taken into account in order to consider the activity as sustainable. This must also be viable in economic terms, because if there is no benefit there will be no agents willing to carry it out and, as right now the price of water is relatively low, it cannot be considered that water purification is a sustainable activity, since the recovery of financial costs is not fulfilled. In addition, low water prices do not reflect the scarcity situation or the costs of water treatment in purification stations, so public financing is necessary to make water treatment viable.

The environmental costs of the activity must be added to the financial costs of recovery, which must also be considered as established by European regulations. The available data clearly show how environmental costs are not being recovered, that is, they are not being able to combat the negative environmental impact of water treatment, without even reaching the recovery of financial costs, so the activity currently is not sustainable and there are still important efforts to be made.

These efforts should be aimed at completing the recovery of both types of costs and are closely linked to the water policy, especially the water pricing policy, which is the main form of financing these activities either through the price of water or through taxes on the consumption of this resource.

The aforementioned environmental impact consists mainly in the energy cost of the water purification activity, which is also a large part of the operating cost of purification stations, so energy efficiency in these facilities is essential to transform the Water purification in an economically and environmentally sustainable activity. In addition, when making these efforts, it must be taken into account that energy consumption varies depending on the facilities, observing an energy consumption per cubic meter of treated water lower as greater is the amount of treated water, which will determine the way to improve energy efficiency. Overall, $80.5 \%$ of the energy used in the process of water purification and reuse in the Valencian community comes from non-renewable sources which, given the current situation of global warming and climate change, it is very important to avoid as much as possible to consider this activity as sustainable.

In addition, although energy efficiency is a key aspect of the environmental impact of water treatment, the ability of water pricing policy to influence consumers should not be underestimated, since an appropriate policy could lead to a more efficient use of water, which is a scarce resource. This type of measures is complementary to energy improvements and allow us to relieve the pressure on resources. 


\section{APPENDIX}

- Confederación Hidrográfica de Ceuta, Memoria. Plan hidrológico de la Demarcación Hidrográfica de Ceuta, 2015. www.chguadalquivir.es/demarcacion-hidrograficaceuta\#Segundociclodeplanificaci\%C3\%B3n(2016-2021). Accessed on: 7 Feb. 2019.

- Confederación Hidrográfica de Melilla, Memoria. Plan hidrológico de la Demarcación Hidrográfica de Melilla, 2015. www.chguadalquivir.es/demarcacion-hidrograficamelilla\#Segundociclodeplanificaci\%C3\%B3n(2016-2021). Accessed on: 7 Feb. 2019.

- Confederación Hidrográfica del Cantábrico, Anejo 09. Recuperación de costes de los servicios del agua. Plan hidrológico de la Demarcación Hidrográfica del Cantábrico Occidental 2015-2021, 2015. www.chcantabrico.es/dhc-occidental. Accessed on: 7 Feb. 2019.

- Confederación Hidrográfica del Cantábrico, Memoria. Plan hidrológico de la parte española de la Demarcación Hidrográfica del Cantábrico Oriental, 2015. www.chcantabrico.es/parte-espaniola-de-la-dhc-oriental. Accessed on: 7 Feb. 2019.

- Confederación Hidrográfica del Duero, Memoria de Plan hidrológico 2015-2021. Plan hidrológico de la parte española de la Demarcación Hidrográfica del Duero, 2015. www.chduero.es/Inicio/Planificaci\%C3\%B3n/Planhidrol\%C3\%B3gico20152021/Plan Hidrol\%C3\%B3gico/tabid/734/Default.aspx. Accessed on: 7 Feb. 2019.

- Confederación Hidrográfica del Ebro, Memoria. Plan hidrológico de la parte española de la Demarcación Hidrográfica del Ebro, 2015.

www.chebro.es/contenido.visualizar.do?idContenido=42695\&idMenu=4780. Accessed on: 7 Feb. 2019.

- Confederación Hidrográfica del Guadalquivir, Memoria. Plan hidrológico de la Demarcación Hidrográfica del Guadalquivir, 2015. www.chguadalquivir.es/ demarcacion-hidrografica-guadalquivir\#Segundociclodeplanificaci\%C3\%B3n(20162021). Accessed on: 7 Feb. 2019.

- Confederación Hidrográfica del Guadiana, Memoria (Parte II). Plan hidrológico de la Demarcación Hidrográfica del Guadiana, 2015.

http://planhidrologico2015.chguadiana.es/?corp=planhidrologico2015\&url=61. Accessed on: 7 Feb. 2019.

- Confederación Hidrográfica del Júcar, Memoria. Plan hidrológico de la Demarcación Hidrográfica del Júcar, 2015.

www.chj.es/es-es/medioambiente/planificacionhidrologica/Paginas/PHC-2015-2021Plan-Hidrologico-cuenca.aspx. Accessed on: 7 Feb. 2019.

- Confederación Hidrográfica del Miño-Sil, Capítulo 9. Recuperación de costes de los servicios del agua. Plan hidrológico de la Demarcación Hidrográfica del Miño-Sil, 2015. www.chminosil.es/es/chms/planificacionhidrologica/plan-hidrologico-2015-2021vigente-rd-1-2016/80-chms/1359-plan-hidrologico-2015-2021-rd-1-2016. Accessed on: 7 Feb. 2019.

- Confederación Hidrográfica del Segura, Memoria. Plan hidrológico de la Demarcación Hidrográfica del Segura 2015-2021, 2015.

www.chsegura.es/chs/planificacionydma/planificacion15-21/. Accessed on: 7 Feb. 2019.

- Confederación Hidrográfica del Tajo, Documentos iniciales. Memoria. Plan hidrológico de la parte española de la Demarcación Hidrográfica del Tajo. Revisión de tercer ciclo (2021-2027), 2018. www.chtajo.es/LaCuenca/Planes/PlanHidrologico/Planif_20212027/Paginas/default.aspx. Accessed on: 7 Feb. 2019. 


\section{REFERENCES}

[1] Prats, D., La reutilización de aguas depuradas regeneradas a escala mundial: análisis y prospectivas. Agua y Territorio, 8, pp. 10-21, 2016.

[2] Navarro, T., Water reuse and desalination in Spain: Challenges and opportunities. Journal of Water Reuse and Desalination, 8(2), pp. 153-168, 2018.

DOI: $10.2166 /$ wrd.2018.043.

[3] Trapote, A., Tecnologías de depuración y reutilización: nuevos enfoques. Agua y Territorio, 8, pp. 48-60, 2016.

[4] United Nations Water, The United Nations World Water Development Report 2017: Wastewater: An untapped resource. United Nations: Paris.

www.unwater.org/publications/world-water-development-report-2017/. Accessed on: 7 Feb. 2019.

[5] Melgarejo, J., Efectos ambientales y económicos de la reutilización del agua en España. CLM Economía, 15, pp. 245-270, 2009.

[6] European Union, Directive 2000/60/EC of the European Parliament and of the Council of 23 October 2000 establishing a framework for Community action in the field of water policy. https://eur-lex.europa.eu/eli/dir/2000/60/oj?locale=en. Accessed on: 7 Feb. 2019.

[7] Torregrosa, T., Valoración económica de los recursos naturales. Master's Degree in Applied Economics, University of Alicante, Spain, 2017.

[8] Yongguan, C., Seip, H.M. \& Vennemo, H., The environmental cost of water pollution in Chongqing, China. Environment and Development Economics, 6(3), pp. 313-333, 2001. DOI: 10.1017/S1355770X01000183.

[9] Molinos, M., Hernández, F. \& Sala, R., Viabilidad económica de la reutilización de aguas residuales: valoración económica de los beneficios ambientales. Anales de ASEPUMA, 18, 2010.

[10] Alcon, F., Martin-Ortega, J., Berbel, J. \& De Miguel, M.D., Environmental benefits of reclaimed water: An economic assessment in the context of the Water Framework Directive. Water Policy, 14(1), pp. 148-159, 2012. DOI: 10.2166/wp.2011.001.

[11] Comos, J.A., Reutilización de las aguas depuradas en la vega de Valencia. Aplicación

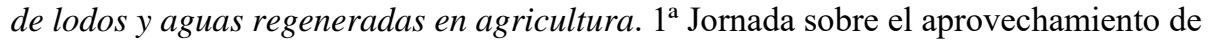
recursos disponibles en una EDAR, Valencia, 2014.

[12] Villar, A., Reutilización de aguas regeneradas: aproximación a los costes de producción y valoración de su uso. Agua y Territorio, 8, pp. 70-79, 2016.

[13] Melgarejo, J. \& Esteve, S., Estudio económico comparativo del Canon de Saneamiento en España. Ejemplo de éxito en la comunidad valenciana. Desafíos del Derecho de Aguas, Aranzadi, Pamplona, 2016.

[14] iAgua, Eficiencia energética en las estaciones depuradoras de aguas residuales. iAgua Magazine, 4, 2014.

[15] Instituto para la Diversificación y Ahorro de la Energía, Estudio de prospectiva. Consumo energético en el sector del agua. www.idae.es/uploads/documentos/ documentos_Estudio_de_prospectiva_Consumo_Energetico_en_el_sector_del_agua 2010_020f8d̄b6.pdf. Accessed on: 7 Feb. 2019.

[16] EPSĀR, Memoria de Gestión 2017. Entidad Pública de Saneamiento de Aguas Residuales de la Comunidad Valenciana: Valencia, 2018. 